\title{
Pembelajaran Bahasa Arab di Pondok Modern Darussalam Gontor
}

\author{
Pradi Khusufi Syamsu \\ Institut Agama Islam Negeri (IAIN) Syekh Nurjati Cirebon \\ Email: pradikhusufi@gmail.com
}

\begin{abstract}
This article confirms that learning Arabic in Pondok Modern Darussalam Gontor is very integrative. Arabic learning is taught in an integrated classroom with the daily lives of students both in the dormitories and in the pesantren and its surroundings. Learning Arabic is not only taught in class but also taught in dormitories every morning and in every corner of the pesantren students can find language learning. Arabic learning for Gontor is not enough. Students are also emphasized to consistently apply Arabic in everyday life by using it in communication. The consequences of students' inconsistency in Arabic will reap punishment both at the dormitory level and at the cross-dormitory level or central language institution. So that the language environment in Gontor which includes five competencies, namely speaking, listening, writing, reading and teaching can be achieved well.
\end{abstract}

Keywords: Arabic Language Learning, Arabic Language, Gontor, Language Environment

\begin{abstract}
Abstrak
Artikel ini menegaskan bahwa pembelajaran bahasa Arab di Pondok Modern Darussalam Gontor sangat integratif. Pembelajaran Bahasa Arab yang diajarkan di kelas-kelas terintegrasi dengan kehidupan keseharian para santri baik di asrama maupun di lingkungan pesantren dan sekitarnya. Pembelajaran bahasa Arab tidak hanya diajarkan di kelas-kelas namun juga diajarkan di asrama setiap paginya dan di setiap sudut pesantren santri dapat menemukan pembelajaran berbahasa. Pembelajaran bahasa Arab bagi Gontor tidak cukup. Para santri juga ditekankan untuk secara konsisten menerapkan bahasa Arab dalam kehidupan sehari-hari dengan menggunakannya dalam komunikasi. Konsekwensi dari inkonsistensi santri dalam berbahasa Arab akan menuai hukuman baik di tingkat asrama maupun di tingkat lintas asrama atau lembaga bahasa pusat. Sehingga lingkungan berbahasa di Gontor yang mencakup lima kompetensi, yakni berbicara, mendengar, menulis, membaca dan mengajar dapat diraih secara baik.
\end{abstract}

Kata Kunci: Pembelajaran Bahasa Arab, Bahasa Arab, Gontor, Lingkungan Berbahasa 


\section{Pendahuluan}

Pondok Modern Darussalam Gontor (PMDG) yang terletak di Kabupaten Ponorogo di koordinat $111^{\circ} 17^{\prime}-111^{\circ} 52^{\prime}$ BT dan $7^{\circ} 4^{\prime}-8^{\circ}$ 20' LS dengan ketinggian antara 92 sampai dengan 2.563 meter di atas permukaan laut ${ }^{1}$ ini dinilai pesantren yang sangat kompeten dan terpercaya dalam menghasilkan lulusan yang cakap berbahasa Arab baik secara lisan maupun tulisan. Kecakapan berbahasa Arab yang dimiliki para santri dan lulusannya tentu bukan didapat secara instan. Namun, kecapakan itu merupakan proses yang panjang dan kontinyu lagi metode pembelajarannya yang jitu sehingga memenuhi target apa yang diharapkan.

Mengkaji lebih dalam tentang pembelajaran bahasa Arab di PMDG tentu sangat menarik dan relevan. Terlebih pembelajaran bahasa Arab di Gontor sangat berbeda dengan pesantren kebanyakan dan terbilang modern. Artinya, Gontor telah melakukan terobosan baru dalam pembelajaran bahasa Arab sehingga menghasilkan santri dan lulusan yang aplikatif dalam berbahasa Arab baik lisan maupun tulisan. Bagaimanakah pembelajaran bahasa Arab di PMDG? Metode apa yang digunakan? Dan bagaimana lingkungan berbahasa (language environment) tercipta? Artikel sederhana ini menjawab ketiga pertanyaan tersebut.

\section{Sejarah Berdirinya Pondok Modern Darussalam Gontor}

Pondok Modern Darussalam Gontor (PMDG) tidak lahir secara tiba-tiba. Ada latar belakang sejarah yang panjang sehingga PMDG berdiri. Dapat dikatakan bahwa PMDG merupakan hasil metamorfosa dari Pesantren Tegalsari dan Gontor Lama. Pesantren Tegalsari sendiri berdiri di awal ke-18 dengan seorang kiai ternama Kiai Ageng Muhammad Bashari (Besari). ${ }^{2}$ Nama Tegalsari diambil dari nama desa dimana pondok ini berada.

Pesantren Tegalsari pernah mengalami masa kejayaan atau keemasan berkat kepiawaian, kealiman, dan kharisma sang kiai dalam mengasuh. Pada saat itu ribuan santri berduyun-duyun berlajar di pondok ini. Para santrinya pun dari latar belakang yang beragam dan dari seantero pulau Jawa. Besarnya jumlah santri menyebabkan seluruh desa Tegalsari menjadi pemondokan bagi para santri. Bahkan

\footnotetext{
${ }^{1}$ https://ponorogo.go.id/letak-geografis/

${ }^{2}$ KH Abdullah Syukri Zarkasyi, Gontor dan Pembaharuan Pendidikan Pesantren. (Jakarta: Rajawali Pers, 2005). Hal. cover belakang. Hal. 88.
} 
pemondokan santri meluas ke desa-desa sekitar, seperti desa Jabung, desa Bantengan dan lain-lain.

Besarnya jumlah santri dari berbagai daerah dan bermacam latar belakang menunjukkan masyhurnya Tegalsari pada kala itu. Tercatat, Paku Buana II atau Sunan Kumbul penguasa kerajaan Kartasura, Raden Ngabehi Ronggowarsito, dan HOS Cokroaminoto pernah menimba ilmu di pesantren Tegalsari. Hasil didikan pesantren Tegalsari ini banyak berkiprah di berbagai bidang di masyarakat sepulang dari pesantren, baik menjadi kiai, ulama, pejabat, budayawan, negarawan, pengusaha dan lain-lain.

Eksistensi pesantren Tegalsari terus berjalan hingga pertengahan abad ke-19. Setelah Kiai Ageng Hasan Besari, pesantren Tegalsari dipimpin oleh Kiai Hasan Yahya, putra ketujuh Kiai Ageng Hasan Besari. Kemudian Tegalsari dipimpin oleh Kiai Hasan Bagus Bashori II lalu dilanjutkan oleh Kiai Hasan Anom Besari. Kemunduran pesantren Tegalsari telah nampak pada generasi keempat, yaitu pada pertengahan abad ke-19 semenjak wafatnya Kiai Hasan Anom Besari. ${ }^{3}$

Pada masa kepemimpinan Kiai Khalifah di pesantren Tegalsari, terdapat seorang santri yang sangat menonjol dalam berbagai bidang. Adalah Sulaiman Jamaluddin santri tersebut. Ia putra penghulu Jamaluddin dan cucu dari Pangeran Hadiraja dari kesultanan Kasepuhan Cirebon. Akhirnya Sulaiman Jamaluddin dijadikan menantu sang kiai. Sering kali ia menggantikan sang kiai untuk memimpin pesantren di kala kiai Khalifah berhalangan hadir. Kepercayaan sang kiai waktu demi waktu kepadanya pun bertambah. Sang menantu dipercaya untuk mendirikan pesantren di desa Gontor. ${ }^{4}$

Dengan dibekali ilmu yang mumpuni dan 40 santri oleh Kiai Khalifah, Kiai Sulaiman Jamaluddin berangkat ke desa Gontor beserta rombongannya. Desa yang berada $3 \mathrm{KM}$ sebelah timur Tegalsari dan 11 KM dari kota Ponorogo ini masih berupa hutan yang jauh dari kehidupan manusia kala itu. Para perampok, penyamun, penjahat, dan pemabuk menjadikan tempat ini sebagai tempat persembunyiaannya. Karena itu kawasan ini dijuluki sebagai "tempat kotor" yang dalam

${ }^{3}$ KH Abdullah Syukri Zarkasyi, Gontor dan Pembaharuan Pendidikan Pesantren. (Jakarta: Rajawali Pers, 2005). Hal. cover belakang. Hal. 89.

${ }^{4} \mathrm{KH}$ Abdullah Syukri Zarkasyi, Gontor dan Pembaharuan Pendidikan Pesantren. (Jakarta: Rajawali Pers, 2005). Hal. cover belakang. Hal. 89-90. 
bahasa Jawa disebut dengan enggon kotor. Nama desa Gontor pun berasal dari ungkapan enggon kotor ini yang kemudian disingkat menjadi Gontor. ${ }^{5}$ Namun hal itu tidak menyurutkan semangat juang kiai muda dalam merintis pesantren untuk dakwah Islam.

Sejatinya kebanyakan pesantren didirikan di ranah yang sarat dengan kemaksiatan dan jauh dari nilai ekonomis. Sejarah mencatat bahwa pesantren-pesantren yang didirikan di tempat yang secara ekonomi, religius, dan sumber daya manusia tidak menguntungkan ini menjelma menjadi pesantren besar. Pesantren merubah wilayah sekitarnya menjadi kekuatan ekonomi yang mandiri dan sarat dengan nilai-nilai religiusitas serta memunculkan sumber daya manusia yang kompetitif. Walhal pesantren mengundang banyak santri dari berbagai wilayah untuk belajar.

Berdirinya pesantren di wilayah yang tidak produktif memiliki kemiripan dengan kisah Nabi Ismail as dan ibundanya Siti Hajar ketika ditinggal Nabi Ibrahim as di tengah lembah gurun pasir yang tidak berpenghuni dan sangat gersang sehingga tidak satu pohon pun yang tumbuh di lembah tersebut. Namun karena titah Nabi Ibrahim as merupakan perintah Allah SWT, Siti Hajar dengan penuh keikhlasan menerimanya. ${ }^{6}$ Buah keikhlasannya akhirnya memberikan berkah bagi seluruh umat Islam di dunia sampai sekarang ini. Lembah gurun pasir tidak berpenghuni itu kemudian menjelma menjadi qiblat umat Islam dan puncak rukun Islam. Maka begitu juga pesantren-pesantren yang ada di Indonesia yang mampu menjelma menjadi pusat peradaban karena dilandaskan ketakwaan dan keikhlasan dalam berdakwah di jalan Allah SWT.

Pondok Gontor yang didirikan oleh Kiai Sulaiman Jamaluddin berkembang pesat. Terutama di masa kepemimpinan puteranya yang bernama Kiai Archam Anom Besari. Para santri datang dari seantero pulau Jawa, bahkan tidak sedikit yang berasal dari Tanah Pasundan. Kiai Archam Anom Besari wafat. Ia pun digantikan oleh puteranya yang bernama Santoso Anom Besari. Kiai Santoso Anom Besari adalah

\footnotetext{
${ }^{5}$ KH Abdullah Syukri Zarkasyi, Gontor dan Pembaharuan Pendidikan Pesantren. (Jakarta: Rajawali Pers, 2005). Hal. 90.

${ }^{6}$ Lihat Abu Abdillah Muhammad bin Isma'il Al Bukhari, Matan Al Bukhari, Jilid 2. (Beirut: Dar al Fikr, 2006). Hal. 270-271. Lihat juga M.M Al A'zami, The History of the Qur'anic Text; from Revelation to Compilation, alih bahasa Sohirin Solihin, Anis Malik Thaha, Ugi Suharto dan Lili Yuliadi. (Jakarta: GIP, 2005). Hal. 16.
} 
generasi ketiga Pondok Gontor Lama. Pada masa kepemimpinan beliau, Gontor mulai surut. Kegiatan pembelajaran dan pendidikan di pesantren mulai menurun dikarenakan kealpaan kaderisasi. ${ }^{7}$

Masjid kecil yang tadinya ramai menjadi sepi dari santri mengaji, shalat, dan belajar. Namun kondisi ini tidak membuat Kiai Santoso Anom Besari larut dalam kemunduran. Ia pun tetap berjuang menegakkan kalimat Allah di bumi Gontor. Nyatanya, masyarakat Gontor dan sekitarnya tetap menjadikannya figur, tokoh, dan rujukan dalam berbagai macam pesoalan agama. Kiai Santoso Anom Besari tidak berumur panjang. Ia wafat dalam umur yang belum begitu tua. Sepeninggalannya kejayaan Gontor Lama akhirnya benar-benar sirna.

Isteri Kiai Santoso Anom Besari tidak patah semangat meski sang suami telah wafat. Tekad Nyai Santoso menghidupkan kembali kejayaan Gontor diwujudkannya dengan mengirim tiga orang puteranya ke beberapa pesantren dan lembaga pendidikan lain guna memperdalam ilmu-ilmu keislaman. Ketiganya adalah Ahmad Sahal, Zainuddin Fanani, dan Imam Zarkasyi. ${ }^{8}$

Sepeninggal Kiai Santoso masyarakat desa Gontor seperti kuda lepas dari kandang. Jauh dari sifat terpelajar. Mereka menjadi masyarakat yang tidak kenal dengan Islam. Perilaku mencuri, main perempuan, menghisap candu, mabuk, dan main judi atau sudah menjadi tradisi ${ }^{9}$. Belum lagi budaya gemblakan di kalangan para warok yang terus mewabah. ${ }^{10}$

Cita-cita luhur Nyai Santoso untuk mengembalikan kejayaan Gontor tercapai. 12 Rabi'ul Awwal 1345 atau 20 September $1926 \mathrm{KH}$ Abdullah Sahal, sebagai saudara tua dan telah lebih dahulu menyelesaikan rihlah ilmiyahnya ke berbagai pesantren, mendeklarasikan pembukaan kembali Pondok Gontor di hadapan masyarakat pada peringatan Maulid Nabi. ${ }^{11}$ Pondok ini awalnya

${ }^{7}$ KH Abdullah Syukri Zarkasyi, Gontor dan Pembaharuan Pendidikan Pesantren. (Jakarta: Rajawali Pers, 2005). Hal. 90-91.

8 Nur Hadi Ihsan dan Muhammad Akrimul Hakim, Profil Pondok Modern Darussalam Gontor. (Ponorogo: Pondok Modern Darussalam Gontor, 2004). Hal. 3.

${ }^{9}$ Pondok Modern Darussalam Gontor, KH. Imam Zarkasyi dari Gontor Merintis Pesantren Modern. (Ponorogo: Gontor Press, 1996). Hal. 41.

${ }^{10}$ Nur Hadi Ihsan dan Muhammad Akrimul Hakim, Profil Pondok Modern Darussalam Gontor. (Ponorogo: Pondok Modern Darussalam Gontor, 2004). Hal. 3.

${ }^{11}$ Pondok Modern Darussalam Gontor, KH. Imam Zarkasyi dari Gontor Merintis Pesantren Modern. (Ponorogo: Gontor Press, 1996). Hal. 41. 
dinamakan Darussalam, kemudian 19 Desember 1936 pada syukuran satu dasarwarsa pondok naman modern disematkan secara resmi sehingga nama lengkap pondok menjadi Pondok Modern Darussalam Gontor yang kemudian biasa disingkat menjadi Pondok Gontor atau Pondok Modern atau terkadang juga cukup disebut Gontor. ${ }^{12}$

Tarbiyatul Afhfal (TA) adalah langkah awal dalam memhidupkan kembali Pondok Gontor. TA adalah program pendidikan yang diperuntukan bagi anak-anak masyarakat Gontor yang dalam perjalanan selanjutnya diramaikan juga oleh orang-orang dewasa. Materi, prasarana, dan sarananya masih sangat sederhana. Belajar hanya beralaskan tikar dan daun kelapa baik pada siang hari maupun malam hari.

KH. Ahmad Sahal dengan panggilan populer Pak Sahal secara langsung mendidik para santri TA. Kesabaran, kegigihan dan keuletan Pak Sahal dalam mendidik menuai hasil yang signifikan. Setelah 3 tahun jumlah santri mencapai 300. Selain dari desa Gontor, mereka juga datang dari desa-desa sekitar Gontor. Dan, mereka pun tidak dipungut biaya sama sekali. Bahkan keperluan sehari-hari mereka tidak jarang ditanggung oleh pengasuh Pondok Gontor. Sebab tujuan pembelajaran TA adalah penyadaran santri akan pemahaman dan pengamalan ajaranajaran Islam.

7 tahun berlangsung, murid-murid TA mencapai 500 baik putera maupun puteri. Karena fasilitas belajar belum memadai, mereka pun menjadikan rumah-rumah penduduk dan alam terbuka sebagai tempar belajar. Semangat membangun gedung untuk ruang belajar semakin terasa namun dana belum ada. Maka dibentuklah Anshar Gontor yang bertugas mengumpulkan dana dari seluruh pulau Jawa guna merealisasikan pembangunan gedung sebagai tempat belajar para santri TA. Para santri tidak tinggal diam, mereka juga dilibatkan dalam pembuatan bata merah. ${ }^{13}$

Seiring berjalannya waktu TA semakin berkembang pesat. Cabang-cabang TA berdiri di desa-desa sekitar Gontor. Madrasahmadrasah TA di sekitar Gontor ditangani oleh kader-kader Gontor

${ }^{12}$ KH Abdullah Syukri Zarkasyi, Gontor dan Pembaharuan Pendidikan Pesantren. (Jakarta: Rajawali Pers, 2005). Hal. 93.

13 Nur Hadi Ihsan dan Muhammad Akrimul Hakim, Profil Pondok Modern Darussalam Gontor. (Ponorogo: Pondok Modern Darussalam Gontor, 2004). Hal. 3-4. 
melalui kursus pengkaderan. Mutu TA terus dikembangkan demi terbentuknya lulusan-lulusan yang kompeten agar dapat berkiprah di beberapa TA cabang yang ada. Maka Sullamul Muta'allimin akhirnya dibuka sebagai jenjang pendidikan di atas TA. ${ }^{14}$

Sullamul Muta'allimin didirikan seiring semakin banyaknya lulusan TA yang bersemangat belajar ke jenjang yang lebih tinggi. Tepatnya tahun 1932 Pengasuh Gontor membuka program lanjutan ini. Pembelajaran di tingkat Sullamul Muta'allimin ini lebih kompleks ketimbang TA. Para santri belajar lebih dalam dan luas mengenai ilmuilmu keislaman seperti fikih, hadits, tafsir, terjemah al Qur'an, pidato, diskusi, ilmu jiwa, dan ilmu pendidikan. Selain itu para santri juga dibekali dengan skill di berbagai bidang seperti seni, olahraga, gerakan kepanduan dan lain-lain.

Tiga tahun Sullamul Muta'allimin berjalan, kegiatan ekstrakulikuler terkait latihan kepemimpinan dan gerakan kepemudaan makin bertambah, antara lain: Tarbiyatul Ikhwan (Organisasi Pemuda), Tarbiyatul Mar'ah (Organisasi Pemudi), Muballighin (Organisasi Juru Dakwah), Bintang Islam (Gerakan Kepramukaan), Riyadhatul Badaniyah Tarbiyatul Athfal (Organisasi Olahraga), Miftahussa'adah dengan Mardi Kasampurnaan, Klub Seni Suara, dan Klub Teater. ${ }^{15}$

Upaya pengasuh Pondok menuai hasil. TA cabang semakin menjamur di desa sekitar Gontor. Maka dibentuklah Taman Perguruan Islam (TPI) yang mewadahi seluruh TA dimana TPI dipimpin langsung oleh Pak Sahal. Para Alumni TA dan Sullamul Muta'allimin mengambil peran dalam proses pembelajaran di semua cabang TA yang tersedia. Diumur Gontor yang kesepuluh tahun TPI telah memiliki murid lebih dari 1000. Gairah belajar masyarakat makin terlihat. Pondok Gontor pun tidak berhenti untuk berkreasi dalam menyempurnakan programprogram pendidikannya.

Peringatan 10 tahun Pondok Gontor diselenggarakan. Waktu itu, KH Imam Zarkasyi baru satu tahun pulang dari rihlah ilmiyyah-nya di Padang Panjang Sumatera Barat. Peringatan 10 tahun Pondok ditandai dengan pembukaan program pendidikan baru untuk tingkat menengah

${ }^{14} \mathrm{KH}$ Abdullah Syukri Zarkasyi, Gontor dan Pembaharuan Pendidikan Pesantren. (Jakarta: Rajawali Pers, 2005). Hal. cover belakang. Hal. 92.

${ }^{15}$ Nur Hadi Ihsan dan Muhammad Akrimul Hakim, Profil Pondok Modern Darussalam Gontor. (Ponorogo: Pondok Modern Darussalam Gontor, 2004). Hal. 4-5. 
pertama dan atas yang bernama Kulliyatul Mu'allimin al-Islamiyyah (KMI) yang berarti Persemaian Guru-guru Islam. KMI resmi dibuka 19 Desember 1936 yang dipimpin langsung oleh KH Imam Zarkasyi. Sebelumnya ia pernah memimpin lembaga pendidikan serupa namun untuk pelajar perempuan di Padang Sidempuan, Sumatera Utara, yang bernama $\mathrm{Mu}^{\prime}$ allimat Muhammadiyah. ${ }^{16}$

Peringatan sepuluh tahun Pondok juga ditandai dengan dicetuskannya nama baru bagi pondok Gontor, yakni Pondok Modern Darussalam Gontor. Pada awalnya pondok Gontor bernama Darussalam tapi karena kemodernan pendidikannya pada zaman itu masyarakat pun menyebut Pondok Modern Darussalam Gontor (PMDG) ${ }^{17}$

KMI PMDG hampir mirip dengan Sekolah Noormal Islam di Padang Panjang, tempat dimana Pak Zar, demikian panggilan populer KH Imam Zarkasyi, menempuh jenjang pendidikan menengahnya. Namun KMI PMDG tetap memiliki originalitas karena mampu memadukannya dengan tradisi pesantren yang berkembang di Jawa. Santri KMI pun tinggal di asrama dengan proses pendidikan 24 jam non stop. Pelajaran agama dan ilmu non agama diajarkan secara berimbang di setiap tingkatannya. Pendidikan keterampilan, kesenian, olahraga, organisasi, kedisiplinan, bahasa, dan entrepreneurship menjadi bagian kehidupan sehari-hari santri di asrama. ${ }^{18}$

Tahun pertama pembukaan KMI memang belum mendapat sambutan yang baik. Kritik dan ejekan tidak jarang menghampiri program baru yang diimplementasikan di Gontor. ${ }^{19}$ Sistem klasikal, tidak mengikuti mainstream kajian kitab-kitab pesantren yang ada, pemberian pelajaran umum sampai dengan pemakaian sarung, kemeja dan dasi menjadi sorotan masyarakat.

Sistem pendidikan pesantren yang tidak umum ini menyebabkan merosotnya jumlah santri. Santri hanya tersisa 16 orang dari ratusan jumlahnya. Pak Zar pun tidak terpengaruh, malah tekadnya semakin

\footnotetext{
${ }^{16}$ Pondok Modern Darussalam Gontor, KH. Imam Zarkasyi dari Gontor Merintis Pesantren Modern. (Ponorogo: Gontor Press, 1996). Hal. 49-50.

${ }^{17}$ KH Albdullah Syukri Zarkasyi, Gontor dan Pembaharuan Pendidikan Pesantren. (Jakarta: Rajawali Pers, 2005). Hal. 93.

${ }^{18}$ Pondok Modern Darussalam Gontor, KH. Imam Zarkasyi dari Gontor Merintis Pesantren Modern. (Ponorogo: Gontor Press, 1996). Hal. 51.

${ }_{19}$ Mastuki HS dan M. Ishom El-Saha (ed), Intelektualisme Pesantren, seri ketiga. (Jakarta: Diva Pustaka, 2003). Hal. 36.
} 
kuat dengan berkata, "Biarpun tinggal satu saja dari yang 16 ini, program akan tetap kami jalankan sampai selesai, namun yang satu itulah nanti akan mewujudkan 10, 100, hingga 1000 orang." Pak Sahal juga berdoa mendukung program pendidikan yang diusung adiknya itu: "Ya Allah, kalau sekiranya saya akan emlihat bangkai Pondok saya ini, panggilah saya lebih dahulu kehadirat-Mu untuk mempertanggungjawabkan urusan ini." 20

Tahun kedua KMI dibanjiri santri dari berbagai daerah di Indonesia mulai dari Kalimantan, Sumatera dan hampir dari seluruh Tanah Jawa. Tahun ketiga, KMI semakin diramaikan dengan santri berasal dari perkotaan Tanah Air. Tingkat kemampuan mereka pun berbeda beda. Untuk menyikapi kesenjangan kemampuan dibukalah kelas khusus untuk menampung mereka yang pengetahuannya tidak memadai yang bernama voorklas atau kelas pendahuluan.

Setelah lima tahun, KMI dikembangkan menjadi dua tingkatan, yakni program Onderbow dengan lama belajar 3 tahun dan Program Bovenbow dengan masa belajar 2 tahun. Program-program KMI terus mengalami perkembangan, saat ini KMI memiliki 2 program yang berbeda dari sebelumnya. Program reguler dan program intensif merupakan respon KMI terhadap perkemangan zaman. Program reguler diperuntukkan bagi lulusan Madrasah Ibtidaiyah atau Sekolah Dasar dengan masa studi 6 tahun. Sedang program intensif diperuntukkan bagi lulusan Madrasah Tsanawiyah atau Sekolah Menengah Pertama dengan masa studi 4 tahun. Kelas atau program intensif hanya dilaksanakan di kelas 1 dan 3, yakni kelas 1 intensif dan kelas 3 intensif. Adapun kelas 5 dan 6 berjalan secara reguler. Sehingga lulusan MI/SD dan MTs/SMP akan bersama-sama di kelas 5 dan 6 .

Lulusan Pondok Gontor terlebih dahulu diakui oleh negaranegara di Timur Tengah, Asia, dan Eropa ketimbang Indonesia. Baru pada tahun 1999 dan 2000 pengakuan Pemerintah Indonesia akan lulusan Gontor diterbitkan Departemen Agama dan Departemen Pendidikan Nasional. Tidak diakuinya Gontor oleh Pemerintah Indonesia selama puluhan tahun merupakan imbas dari Undang-undang

${ }^{20} \mathrm{KH}$. Abdullah Syukri Zarkasyi MA, Manajemen Pesantren, Pengalaman Pondok Moder Gontor. (Ponorogo: Trimurti Press, 2005). Hal. 68-69. 
Pendidikan Nasional dan politik pendidikan nasional yang tidak berpihak kepada pesantren. ${ }^{21}$

\section{Bahasa Arab dalam Kurikulum PMDG}

Kurikulum KMI Gontor sangat berbeda dengan sekolah mua'llimin/mu'allimat atau yang sederajat di manapun. Sekalipun pondok alumni, tetap masih belum mampu menerapkan kurikulum KMI secara total. Banyak faktor yang melatarbelakanginya, baik ketersediaan sumber daya guru maupun kompleksitas pelajaran di KMI. Kurikulum KMI disusun secara apik dan sistematis mulai dari kelas satu hingga kelas akhir atau kelas enam. Jika di salah satu tingkatan terdapat ketidak pahaman bahasa maka akan berdampak kepada tingkat selanjutnya. Karena hampir semua pelajaran di KMI berbahasa Arab dan Inggris. Semakin tinggi kelas maka semakin kaya bahasa pengantar di mata pelajarannya.

Jika di kelas satu masih mengikut sertakan bahasa Indonesia maka di tingkat selanjutnya peran bahasa Indonesia dalam mata pelajaran semakin dikurangi kecuali untuk pelajaran Bahasa Indonesia, Berhitung, Matematika, Biologi, IPA, IPS, Kimia, Fisika, Tata Buku, Psikologi Pendidikan, Psikologi Umum, dan Tata Negara.

Secara akademik, kurikulum KMI dapat dibagi beberapa bidang studi, yaitu: pertama, Bahasa Arab meliputi al Imla, al Insya, Tamrin al Lughah, al Muthala'ah, an Nahwu, as Sharf, al Balaghah, Tarikh al Adab, dan al Khat al 'Arabi; kedua, Dirasah Islamiyyah yang meliputi al Qu'an, at Tajwid, at Tawhid, at Tafsir, al Hadits, Mushthalah al Hadits, al Fiqh, Ushul al Fiqh, al Faraidh, al Din Al Islami, Muqaranat al Adyan, Tarikh al Islam, al Mantiq, dan al Tarjamah; ketiga, ilmu keguruan yang mencakup at Tarbiyah wa at Ta'lim dan Psikologi Pendidikan; keempat, Bahasa Inggris yang mencakup Reading and Comprehension, Grammar, Composition, dan Dictation; kelima, Ilmu Pasti antara lain Berhitung dan Matematika; keenam, Ilmu Pengetahuan Alam yang mencakup Biologi, Fisika, dan Kimia; ketujuh, ilmu Pengetahuan Sosial yang meliputi Sejarah Nasional dan Internasional, Geografi, Sosiologi, Tata Buku, dan Psikologi Umum; kedelapan, Keindonesiaan atau Kewarganegaraan yang mencakup Bahasa Indonesia dan Tata Negara.

${ }^{21}$ Lihat Tim Redaksi Nuansa Aulia, Himpunan Perundang-undangan Republik Indonesia tentang Sistem Pendidikan Nasional. (Bandung: Nuansa Aulia, 2008). Hal. 53-69. 
Di bawah buku-buku yang digunakan dalam setiap tingkatan di KMI yang memiliki pengaruh terhadap perkembangan bahasa Arab dan Inggris para santri Gontor.

\begin{tabular}{|c|c|}
\hline \multicolumn{2}{|r|}{ Ragam Buku Ajar Berbahasa Arab } \\
\hline Kelas & Judul Buku \\
\hline 1 & $\begin{array}{l}\text { Durusul Lughah Al Arabiyyah Juz } 1 \text { dan } 2 \\
\text { Al Muthala'ah Al Haditsah } \\
\text { Ilmu Tajwid } \\
\text { Kamus Mahmud Yunus Arab-Indonesia } \\
\text { Kamus Al-Khulali Indonesia-Arab } \\
\text { Kamus Al Munawwir }\end{array}$ \\
\hline 2 & $\begin{array}{l}\text { An Nahwul Wadhih juz } 1 \\
\text { Al Amtsilah At Tasyrifiyyah } \\
\text { Amtsilatul Jumal wa I'rabuha juz } 1 \\
\text { At Tamrinat juz 1-3 } \\
\text { Al Fiqh Al Wadhih juz } 1 \text { dan } 2 \\
\text { Kitab As Sa'adah fi Tawhid } \\
\text { Khulashah Nuril Yaqin } \\
\text { Al Qiraah Ar Rasyidah }\end{array}$ \\
\hline 3 & $\begin{array}{l}\text { An Nahwul Wadhih juz } 2 \\
\text { Amtsilatul Jumal wa I'rabuha juz } 2 \\
\text { Mabadi' Awwaliyyah fi 'Ilm Ushu Al Fiqh wa Al } \\
\text { Qawa'id Al Fiqhiyyah } \\
\text { 'Ilm Mushthalah Al Hadits } \\
\text { Al Adyan } \\
\text { Bulugh Al Maram } \\
\text { ‘Ilm Al Faraidh } \\
\text { Ad Dinul Islamiyyu } \\
\text { Al Qiraah Ar-Rasyid }\end{array}$ \\
\hline 4 & $\begin{array}{l}\text { An Nahwul Wadhih juz } 3 \\
\text { As Sullam fi ‘Ilm Ushul Al Fiqh } \\
\text { At Tarbiyah wa at Ta'lim juz } 1 \\
\text { Bulugh Al Maram } \\
\text { Al Qiraah Ar Rasyidah } \\
\text { Tarikhul Islam }\end{array}$ \\
\hline 5 & $\begin{array}{l}\text { At Tarbiyah wa at Ta'lim juz } 2 \\
\text { An Nahwul Wadhih juz } 3\end{array}$ \\
\hline
\end{tabular}




\begin{tabular}{|l|l|}
\hline & Bulugh Al Maram \\
& Bidayatul Mujtahid wanihayatul Muqtashid \\
& Al Qiraah Ar Rasyidah \\
& Al Munjid fi Al Lughah wa al 'Alam \\
& Ushul Al Fiqh \\
& Tarikh Adab Al Lughah \\
\hline & An Nahwul Wadhih juz 3 \\
& At Tarbiyah wa at Ta'lim juz 3 \\
Al Balaghah fi ‘Ilm Al Bayan \\
Al Manthiq \\
Tarikh Al Hadharah Al Islamiyyah \\
& Bulugh Al Maram \\
& Bidayatul Mujtahid \\
\hline
\end{tabular}

\section{Pembelajaran di PMDG}

Al ma'had la yanamu abadan atau pondok tidak pernah tidur seringkali diucapkan oleh para pemimpin pondok dalam even-even besar atau tahunan seperti Khutbatul 'Arsy (Apel Tahunan) ataupun pergantian pengurus Organisasi Pondok Modern Gontor (OPPM) dan Koordinator Gerakan Kepramukaan. Kata-kata itu menggambarkan betapa padat dan berartinya setiap aktifitas santri di dalam pondok yang tidak lepas dari perhatian dan bimbingan pimpinan dan pengasuh pondok serta para pembantu-pembantunya. Nyatanya memang demikian. Tidak ada kegiatan santri yang sia-sia bahkan apa pun yang dilakukan santri harus bernilai ibadah dan pendidikan.

1. Kegiatan Intra kurikuler

KMI memiliki peran sentral dalam kegiatan intra kurikuler yang dimulai dari pukul 07.00 hingga pukul 12.50 WIB. Dan belajar malam mulai pukul 20.00-22.00 di selain malam senin dan malam jum'at. Secara keilmuan para santri digembleng di dalam kegiatan yang dinahkodai oleh KMI. Bahkan pendirian sistem KMI bagian dari modernisasi sistem pendidikan Gontor dimana pada awalnya masih berupa program Tarbiyatul Athfal dan Sullamul Muta'allimin. Dengan pembukaan program KMI maka Tarbiyatul Athfal dan Sullamul Muta'allimin seiring waktu ditutup. Artinya, pendidikan menengah yang diberlakukan di Gontor hanya KMI. 
KMI memiliki peran dalam menentukan keberlangsungan santri di pondok. Pasalnya, setiap tahunnya para santri dihadapkan dengan dua kali ujian, yakni per enam bulan sekali untuk menentukan apakah dia naik kelas atau tidak. Ujian awal tahun biasanya diadakan pada pertengahan bulan Shafar hingga awal bulan Rabi'ul Awwal. Sedang ujian akhir tahun biasanya diselenggarakan pada akhir bulan Rajab hingga pertengahan bulan Sya'ban. Maka jika santri tidak naik kelas akan dimutasi ke pondok-pondok cabang. Dan jika dua kali tidak naik kelas secara berturut-turut maka akan dipulangkan atau dikembalikan kepada orangtuanya.

Ada empat kriteria kelulusan santri Mumtaz (memuaskan), Jayyid Jiddan (sangat bagus), Jayyid (bagus), dan Maqbul (cukup). Adapun Rasib (tidak lulus) adalah predikat bagi yang tidak naik kelas atau tidak lulus dalam ujian kenaikan kelas. Ujian yang dihadapi para santri mencakup ujian lisan (imtihan syafahi) dan ujian tulis (imtihan tahriri) persemesternya. Para santri harus melalui kedua ujian tersebut guna memenuhi salah satu syarat naik kelas.

Dalam ujian syafahi setiap santri diuji oleh 4 orang penguji yang terdiri dari 2 guru dan 2 siswa akhir KMI atau kelas 6 KMI. Untuk materi ujian lisan Fikih terdiri dari membaca al Qur'an, tajwid, ibadah qauliyah, ibadah amaliyah. Sedang materi ujian lisan bahasa Arab terdiri dari muhadatsah, membaca teks Arab, tarjamah, nahwu, sharaf, Mahfuzhat, kosakata Arab (mufradat), dan uslub (idiom). Adapun materi ujian lisan bahasa Inggris antara lain conversation, reading text, translating, grammar, vocabulary, dan idiom. Jadi ada 3 kali ujian lisan yang dihadapi setiap santri per enam bulannya.

Untuk ujian tulis dalam setiap ruangnya diawasi oleh 3 pengawas ujian yang terdiri dari 1 orang guru dan 2 siswa akhir KMI. Ujian kenaikan kelas di Gontor sangat ketat dan betul-betul bil imtihan yukramul mar'u aw yuhanu, yakni dengan ujian seseorang itu bisa dimuliakan dan dihinakan. Mulia karena beretika dalam ujian dan lulus. Hina karena tidak beretika dalam ujian dan tidak lulus. Maka etika ujian sangat diperhatikan betul dan penuh pengawasan. Sehingga bagi santri yang mencontek hukumanya adalah diskors selama satu tahun ajaran atau dipulangkan untuk selamanya.

Setiap ujian tulis akan berlangsung biasanya santri dikumpulkan di depan BPPM (Balai Pertemuan Pondok Modern). Pimpinan pondok 
memberikan dan Direktur KMI memberikan tausiyahnya sebagai bekal mental para santri dalam menghadapi ujian. Selepas ujian tulis berakhir para santri berkumpul di BPPM. Direktur KMI menyampaikan berjalannya ujian tulis dan Pimpinan pondok menyampaikan wejangannya di hadapan santri sebagai rasa syukur telah selesainya ujian dan pembekalan bagi santri untuk menghadapi liburan.

2. Kegiatan ekstrakurikuler

Santri tidak hanya disibukkan dengan kegiatan intrakurikuler. Kegiatan ekstrakurikuler juga turut meramaikan hari-hari para santri. Bahkan kegiatan ekstrakurikuler lebih banyak porsi dan waktunya ketimbang intrakurikuler. Namun keduanya keduanya saling terkait dan sudah berkelitkelindan.

Untuk mendukung berjalannya kegiatan ekstrakulikuler yang apik dibentuklah lembaga Pengasuhan Santri yang membawahi seluruh organisasi santri. Organisasi santri merupakan ujung tombak pelaksanaan kegiataan ekstrakurikuler. Tak ayal seluruh kehidupan santri pun diatur oleh mereka sendiri. Inilah salah satu letak keunikan PMDG dibanding lembaga pendidikan non pesantren. Dimana para santri yang umurnya sebaya mampu mengawasi dan membina temanteman sebayanya mulai dari bangun tidur hingga tidur kembali.

Ada dua organisasi santri di tingkat menengah atau KMI, yaitu Organisasi Pelajar Pondok Modern (OPPM) dan Organisasi Gerakan Kepramukaan. Jika gerakan kepramukaan bertanggung jawab akan terlaksananya kegiatan kepramukaan yang sedikitnya dalam satu pekan satu hari yakni hari kamis, maka OPPM bertanggung jawab di semua kegiatan santri di luar pramuka. Mulai dari ibadah amaliyah, sopan santun, penegakkan disiplin, pembinaan bahasa, belajar muwajjah (tutorial) sore dan malam, latihan pidato, diskusi, seminar, pelatihan, penerbitan karya santri, kursus, olahraga, sampai kegiatan minat dan bakat santri.

\begin{tabular}{|c|c|c|}
\hline \multicolumn{3}{|c|}{ Kegiatan Harian } \\
\hline No & Jam & Kegiatan \\
\hline 1 & 04.00-05.30 & $\begin{array}{l}\text { 1. Bangun tidur. } \\
\text { 2. Shalat Shubuh berjamaah. } \\
\text { 3. Pembinaan kemampuan berbahasa } \\
\text { Arab atau Inggris. }\end{array}$ \\
\hline
\end{tabular}




\begin{tabular}{|l|l|l|}
\hline & & 4. Membaca Al Qur'an. \\
\hline 2 & $05.30-06.00$ & $\begin{array}{l}\text { 1. Olahraga. } \\
\text { 2. Mandi. }\end{array}$ \\
& & $\begin{array}{l}\text { 3. Kursus bahasa, kesenian, } \\
\text { keterampilan, dan lain-lain. }\end{array}$ \\
\hline 3 & $06.00-06.45$ & $\begin{array}{l}\text { 1. Makan pagi. } \\
\text { 2. Persiapan masuk kelas. }\end{array}$ \\
\hline 4 & $07.00-12.50$ & Masuk kelas pagi. \\
\hline 5 & $12.50-13.00$ & Keluar kelas \\
\hline 6 & $13.00-14.00$ & $\begin{array}{l}\text { 1. Shalat Zhuhur berjamaah. } \\
\text { 2. Makan siang. }\end{array}$ \\
\hline 7 & $14.00-15.00$ & Masuk kelas sore. \\
\hline 8 & $15.00-15.45$ & $\begin{array}{l}\text { 1. Shalat Ashar berjamaah. } \\
\text { 2. Membaca Al Qur'an. }\end{array}$ \\
\hline 9 & $15.45-16.45$ & Aktivitas bebas \\
\hline 10 & $16.45-17.15$ & $\begin{array}{l}\text { Mandi dan persiapan ke Masjid untuk } \\
\text { jamaah Maghrib. }\end{array}$ \\
\hline 11 & $17.15-18.30$ & $\begin{array}{l}\text { 1. Shalat maghrib berjamaah. } \\
\text { 2. Membaca Al Qur'an. }\end{array}$ \\
\hline 12 & $18.30-19.30$ & Makan malam. \\
\hline 13 & $19.30-20.00$ & Shalat Isya berjamaah. \\
\hline 14 & $20.00-22.00$ & Belajar malam bersama di kelas-kelas. \\
\hline 15 & $22.00-04.00$ & Istirahat dan tidur \\
\hline & & \\
\hline
\end{tabular}

\begin{tabular}{|l|l|l|}
\hline \multicolumn{2}{|c|}{ Kegiatan Pekanan } \\
\hline No & \multicolumn{1}{|c|}{ Hari } & \multicolumn{1}{c|}{ Kegiatan } \\
\hline 1 & Sabtu & $\begin{array}{l}\text { Tidak ada perubahan jadwal harian. } \\
\text { Pagi hari seperti jadwal harian, malam } \\
\text { hari, setelah jamaah shalat Isya latihan } \\
\text { pidato dalam bahasa Inggris untuk } \\
\text { kelas 1-4, kelas 5 diskusi, dan kelas 6 } \\
\text { menjadi pembimbing untuk kelompok } \\
\text { latihan pidato. }\end{array}$ \\
\hline 3 & Senin & $\begin{array}{l}\text { Tidak terdapat perubahan dari jadwal } \\
\text { harian. }\end{array}$ \\
\hline 4 & Selasa & Pagi hari, seteah jamaah shalat Shubuh, \\
\hline
\end{tabular}




\begin{tabular}{|l|l|l|}
\hline & & $\begin{array}{l}\text { latihan percakapan bahasa } \\
\text { Arab/Inggris, dilanjutkan lari pagi } \\
\text { wajib untuk para santri. }\end{array}$ \\
\hline 5 & Rabu & $\begin{array}{l}\text { Tidak ada perubahan dari jadwal } \\
\text { harian. }\end{array}$ \\
\hline 6 & Kamis & $\begin{array}{l}\text { Dua jam terakhir pelajaran pagi } \\
\text { digunakan untuk latihan pidato dalam } \\
\text { bahasa Arab. Siang, 13.45-16.00, latihan } \\
\text { Pramuka. Malam, 20.00-21.30, latihan } \\
\text { pidato atau muhadharah bahasa } \\
\text { Indonesia. }\end{array}$ \\
\hline 7 & Jum'at & $\begin{array}{l}\text { Pagi hari kegiatan percakapan dalam } \\
\text { bahasa Arab/Inggris dilanjutkan } \\
\text { dengan lari pagi wajib. Setelah itu kerja } \\
\text { bakti membersihkan lingkungan } \\
\text { kampus. Selanjutnya acara bebas. }\end{array}$ \\
\hline
\end{tabular}

3. Kedisiplinan

Semua kegiatan santri baik yang bersifat ekstra kurikuler maupun intra kurikuler berjalan dengan baik. Pasalnya, penciptaan lingkungan berdisiplin santri di pondok Gontor berjalan baik dan tidak pandang bulu. Pondok tidak akan segan-segan memberikan punishment atau hukuman kepada siapa saja yang melanggar disiplin pondok baik disiplin ibadah, keamanan, berbahasa, berpakaian, absensi sampai dengan disiplin belajar. ${ }^{22}$ Bahkan anak kiai atau anak pimpinan pondok dihukum sesuai peraturan yang berlaku jika melanggar disiplin. ${ }^{23}$

Berat atau tidaknya sanksi disesuaikan dengan besar dan kecilnya pelanggaran yang dilakukan. Jenis sanksi mulai dari dijemur di bawah terik matahari, dipajang di hadapan para santri, membersihkan lingkungan pondok, dicukur rambutnya hingga botak bagi santri putra, memakai kerudung berwarna merah bagi santri putri sampai dengan diskors selama satu tahun atau dipulangkan dari pondok untuk selamalamanya. Namun, dalam penegakkan disiplin pondok lebih menekankan

${ }^{22}$ KH. Abdullah Syukri Zarkasyi MA, Manajemen Pesantren, Pengalaman Pondok Modern Gontor. (Ponorogo: Trimurti Press, 2005). Hal. 114.

${ }^{23}$ Pondok Modern Darussalam Gontor, KH. Imam Zarkasyi dari Gontor Merintis Pesantren Modern. (Ponorogo: Gontor Press, 1996). Hal. 489-490. 
pada kesadaran preventif dan meminimalisir hukuman fisik sehingga jalannya disiplin lebih baik dan suasana kekeluargaan lebih tampak. ${ }^{24}$

Hukuman-hukuman tersebut dimaksudkan untuk memberikan efek jera bagi pelakunya dan menjadi cermin perbandingan bagi para santri yang lain. Untuk sanksi skors dan dipulangkan, misalnya, biasanya dibacakan dihadapan para santri ba'da shalat maghrib berjamaah di masjid. Nama santri yang bersangkutan, nama orangtuanya, asal daerah dan kesalahnya dibacakan secara runut di hadapan para santri sebagai cermin perbandingan agar santri yang lain tidak melanggar disiplin pondok.

Penegakkan disiplin ini pondok bersifat dinamis. Setiap ba'da maghrib bagian-bagian OPPM dan pengurus asrama atau rayon mengadakan sidang atau mahkamah bagi para pelaku indisipliner. Dimana untuk mendapatkan pelanggar disiplin pengurus OPPM ataupun pengurus asrama menyebarkan mata-mata dari kalangan santri sendiri. Belum lagi santri juga harus dihadapkan dengan disiplin intra kurikuler yang dikelola oleh KMI dan disiplin bahasa khusus bagi kelas 5 dan 6 atau santri senior yang dimonitori oleh para guru yang berada di Language Advisory Council (LAC).

Semua yang berada di pondok serba berdisiplin karena kehidupan pondok mesti bernilai pendidikan. Sesuai dengan jargon pondok, apa yang dilihat, didengar, dirasakan, dan dialami santri seharihari harus mengandung unsur pendidikan. ${ }^{25}$ Selain itu, pemberlakuan disiplin ditujukan untuk mendidik kecerdasan santri secara intelektualemosional, sosial, maupun spiritual. ${ }^{26}$

Untuk menjamin berjalannya pembinaan disiplin santri, pondok lewat lembaga pengasuhan santri membentuk tim khusus yang membimbing tiap-tiap bagian dan kegiatan. Seperti pembimbing asrama, pembimbing pelajaran sore, pembimbing konsulat, pembimbing muhadharah dan diskusi, dan pembimbing bahasa. ${ }^{27}$

${ }^{24}$ KH. Abdullah Syukri Zarkasyi MA, Manajemen Pesantren, Pengalaman Pondok Modern Gontor. (Ponorogo: Trimurti Press, 2005). Hal. 115.

${ }^{25}$ KH Abdullah Syukri Zarkasyi, Gontor dan Pembaharuan Pendidikan Pesantren. (Jakarta: Rajawali Pers, 2005). Hal. 104.

${ }^{26} \mathrm{KH}$. Abdullah Syukri Zarkasyi MA, Manajemen Pesantren Pengalaman Pondok Modern Gontor. (Ponorogo: Trimurti Press, 2005). Hal. 114.

${ }^{27} \mathrm{KH}$. Abdullah Syukri Zarkasyi MA, Manajemen Pesantren Pengalaman Pondok Modern Gontor. (Ponorogo: Trimurti Press, 2005). Hal. 116. 


\section{Strategi Pembelajaran Bahasa}

Biasanya kompetensi dalam berbahasa meliputi empat aspek yakni, mendengar, berbicara, membaca, dan menulis. Empat kompetensi atau skill ini biasa ditemukan dalam buku-buku pembelajaran bahasa asing baik Arab. ${ }^{28}$ Bagi Gontor empat kompetensi berbahasa dirasa kurang dan belum memenuhi target yang ditetapkan pondok. Maka, kemampuan berbahasa ditambah satu lagi sehingga menjadi lima yang tertuang di dalam didaktik-metodik pondok. Kompetensi yang kelima itu ialah kemampuan mengajar dengan baik.

\begin{tabular}{|l|l|l|l|}
\hline \multicolumn{4}{|c|}{ Kompetensi Berbahasa } \\
\hline No & \multicolumn{1}{|c|}{ Istilah Indonesia } & \multicolumn{1}{c|}{ Istilah Arab } & \multicolumn{1}{|c|}{ Istilah Inggris } \\
\hline 1 & Mendengar & Istima' & Listening \\
\hline 2 & Berbicara & Muhadatsah & Speaking \\
\hline 3 & Membaca & Qiraah & Reading \\
\hline 4 & Menulis & Kitabah & Writing \\
\hline 5 & Mengajar & Ta'lim & Teaching \\
\hline
\end{tabular}

Untuk mengasah kelima kemampuan tersebut, pondok Gontor menggunakan integrated system antar dua teori yang saling menopang, yakni: All in one system (nazhariyat al wihdah) dan polysystemic approach (nazhariyat al-furu'). Perpaduan dua sistem tersebut diejawantahkan dalam sistem pengajarannya yang sebagai berikut:

1. Pengajaran bahasa Arab dibagi dalam beberapa materi yang memang merupakan cabang-cabang bahasa Arab, seperti insya', muthalaah, Nahwu, Sharaf, mahfuzhat, khat, dan tarikh adab.

2. Pembagian tersebut dimaksudkan untuk mempermudah proses belajar mengajar sambil memberikan penekanan khusus pada materi-materi dasarnya, nahwu dan sharaf (Arab) .

3. Tidak memisahkan hubungan antar satu materi dengan materi lain, karena pada dasarnya seluruh materi tersebut adalah cabang dari induk yang saling terkait.

4. Dalam proses pengajaran kedua bahasa tersebut pondok Gontor lebih menitik beratkan pada penggunaan direct method atau yang dikenal dengan at thariqah al mubasyirah yang diarahkan kepada penguasaan bahasa secara aktif baik lisan maupun tulisan.

${ }^{28}$ Lihat Ahmad Rusydi Thu'aimah, Ta'lim al-'Arabiyyah lighair an-Nathiqin biha. (Mesir: Jami'ah al Manshurah, 1989). 


\section{Lingkungan Berbahasa}

Siapa saja yang menguasai suatu bahasa bangsa maka ia akan selamat dari tipu dayanya, demikian salah satu ajaran yang ditanamkan pondok kepada santrinya lewat satu judul bahasan pelajaran muthala'ah. Namun, jika menengok ke belakang, pengajaran bahasa Arab dan Inggris di pondok Gontor awalnya terinspirasi oleh Kongres Umat Islam Indonesia yang diadakan di Surabaya pada pertengahan tahun 1926. KH Abdullah Sahal, salah satu pendiri Gontor, turut hadir dalam konferensi itu.

Betapa tidak terenyuh $\mathrm{KH}$ Abdullah Sahal ketika mengetahui tidak adanya cendekiawan Muslim dan ulama yang mampu menguasai bahasa Arab dan Inggris secara bersamaan dalam kongres itu. Karena dalam kongres itu diputuskan bahwa umat Islam di Indonesia mengirimkan utusannya dalam Muktamar Islam Sedunia yang diadakan di Mekkah dimana utusan yang dikirim mesti menguasai bahasa Arab dan bahasa Inggris. Uniknya, kongres yang dihadiri oleh H.O.S. Cokroaminoto, Kiai Mas Mansur, H. Agus Salim, AM. Sangaji, Usman Amin, dan lain-lain tidak ada seorang pun yang menguasai bahasa Arab dan Inggris secara bersamaan. Akhirnya dikirimlah H.O.S. Cokroaminoto yang mahir dalam berbahasai Inggris dan Kiai Mas Mansur yang mahir dalam bahasa Arab. ${ }^{29}$

Maka tekad $\mathrm{KH}$ Abdullah Sahal semakin bulat untuk melahirkan para kader umat Islam yang mampu berbahasa Arab dan Inggris secara bersamaan dan berimbang lewat pesantren yang ia dirikan bersama kedua saudaranya yakni, KH Zainuddin Fanani dan KH Imam Zarkasyi. Bahkan dapat dikatakan pendirian Gontor tidak lepas dari fenomena konferensi umat Islam dimana para pesertanya masih terbilang dikotomistik dalam menyikapi pendidikan dan penguasaan bahasa asing.

Untuk mewujudkan tekad dan niat futuristik tersebut pembelajaran bahasa Arab dan Inggris diberlakukan secara integratif. Pengajaran bahasa dilakukan secara formal maupun informal. Sehingga di Gontor tidak ada area yang bebas dari tidak berbahasa Arab ataupun berbahasa Inggris. Semua penghuni pondok mesti membiasakan diri

${ }^{29}$ Nur Hadi Ihsan dan Muhammad Akrimul Hakim, Profil Pondok Modern Darussalam Gontor. (Ponorogo: Pondok Modern Darussalam Gontor, 2004). Hal. 13. 
untuk berbahasa Arab dan Inggris. Sehingga terciptalah language environment, biah lughawiyah atau lingkungan berbahasa.

Adapun dalam pengajaran bahasa secara formal dilakukan dengan menekankan metode langsung. Adapun langkah-langkah pengajaran bahasa dengan metode langsung antara lain: ${ }^{30}$

1. Pertama guru mengucapkan kata-kata atau kalimat dengan jelas dan terang dengan memilih kalimat-kalimat yang cocok dengan penjelasan kata tersebut atau bisa pula berkaitan dengan materi ajar dan kalimat itu sering digunakan dalam percakapan seharihari. Kemudian para murid menirukan apa yang dikatakan oleh guru dan guru memberikan stimulus atau rangsangan kepada para murid agar menggunakan kata tersebut dalam kalimat yang sesuai dengan kemampuan para murid.

2. Para murid banyak mendapat stimulus agar banyak latihanlatihan baik pendengaran, tulisan, dan lisan.

3. Dalam metode ini guru dilarang keras menterjemahkan kata-kata asing ke dalam bahasa Indonesia guna meningkatkan daya pikir linguistik para murid. Adapun materi bahasa disampaikan secara bertahap, mulai dari nama-nama benda, tempat, kata kerja, kata pengganti orang/tempat, hitungan, bentuk-bentuk, waktu, dan jenis warna. Penggunaan komposisi materi ajar tersebut ditekankan pada cara penyampaian verbal bukan menghafal. Maka ragam contoh didahulukan ketimbang kaidah-kaidah nahwu atau sharaf. Dan, komposisi tersebut ditekankan selama lima bulan dan dilakukan secara berulang-ulang, sehingga dalam waktu lima bulan para murid dapat menguasai dasar-dasar percakapan dan mampu berbahasa walapun masih terbata-bata.

Materi ajar bahasa di setiap tingkatan juga diselaraskan dan dikaitkan dengan penggunaan bahasa dan kecakapan berbahasa di setiap tingkatan kelas. Hal ini terlihat dalam materi ajar berbahasa Arab berikut ini: ${ }^{31}$

${ }^{30}$ KH Abdullah Syukri Zarkasyi, Manajemen Pesantren Pengalaman Pondok Modern Gontor. (Ponorogo: Trimurti Press, 2005). Hal. 153-154.

${ }^{31}$ KH Abdullah Syukri Zarkasyi, Manajemen Pesantren Pengalaman Pondok Modern Gontor. (Ponorogo: Trimurti Press, 2005). Hal. 154. 
1. Kelas 1. Pada tingkatan pertama ini murid mulai disentuh dengan materi-materi ajar berbahasa Arab. Seperti, Aqaid/Tauhid, Tajwid, Tafsir, Hadits, Mahfuzhat, Muhadatsah, dan Muthala'ah.

2. Kelas 2. Bahasa Arab mulai digunakan sebagai bahasa pengantar. Artinya seluruh materi ajar yang bermuatan bahasa Arab diterjemahkan dan disyarh dengan bahasa Arab pula. Walaupun masih cukup sederhana penjelasannya.

3. Kelas 3 dan 4 . Semua mata pelajaran kecuali ilmu pengetahuan umum sudah disampaikan dengan bahasa Arab yang terstruktur.

4. Kelas 5 dan 6. Mulai menjelajahi literature-literatur bahasa Arab. Bahkan dalam level ini mereka sudah dituntut mampu mengajar adik-adik kelasnya dengan menggunakan bahasa Arab secara baik dan benar yang secara langsung dimonitoring oleh guru.

Menurut Pimpinan Pondok KH. Hasan Abdullah Sahal alumni Gontor tidak pintar-pintar amat dalam berbahasa Arab maupun bahasa Inggris. Namun, yang membuat mereka bisa atau mampu berbahasa Arab dan Inggris sepulang dari pondok tidak lain karena self confidentnya yang dalam bahasa Gontor disebut yahanu. Bukan self confident berdasarkan nekat melainkan self confident yang berlandaskan ilmu dan mau belajar kembali. Maka, lanjutnya, dengan self confident atau kepercayaan diri alumni Gontor mampu untuk berbicara dalam bahasa Arab dengan orang Arab dan berbicara dalam bahasa Inggris dengan orang Eropa maupun Amerika.

Namun, bagaimanapun, kecakapan alumni Gontor akan bahasa Arab dan Inggris sudah mengakar di masyarakat Indonesia. Prof. Dr. H.M. Rasyidi mengakui kemajuan Gontor dalam bahasa Arab dan Inggris di banding lembaga-lembaga lain.

"Yang jelas, Pondok Gontor adalah karya fundamentalnya bersama dua kakaknya, dan semua orang Indonesia tahu. Pelajaran bahasa Arabnya maju. Maaf, keluaran pesantren dulu kan hanya bisa baca kitab kuning yang mudah: Jurumiyah, Fath al qarib, dan lain-lain. Dengan Gontor, kalau dibandingkan ya jauh. Apalagi dengan bahasa Inggrisnya, lebih baik daripada lembaga-lembaga lain."32

Penekanan pembelajaran bahasa Arab dan Inggris diakui oleh Karel A. Steenbrink yang pernah mengunjungi Gontor dan "nyantri"

32 Prof. Dr. H.M. Rasyidi, seperti mendapat wahyu, dalam Pondok Modern Darussalam Gontor, KH. Imam Zarkasyi di Mata Umat. (Ponorogo: Gontor Press, 1996). Hal. 628. 
selama tiga bulan. Dalam wawancara dengan KH. Imam Zarkasyi ditulis catatan hariannya bahwa "di Gontor dipentingkan pengetahuan dan keterampilan bahasa". ${ }^{33}$

Lance Castles juga menyaksikan kefasihan santri Gontor dalam berbahasa Inggris dan bahasa Arab ketimbang anak-anak sekolah tingkat atas dalam penelitiannya di Gontor. Baginya, penekanan Arab dan Inggris dengan metode langsung merupakan sesuatu yang unik di Indonesia. Tidak mengherankan jika kefasihan berbahasa Arab dan Inggris menghantarkan santri Gontor untuk studi di Al Azhar Kairo dan di berbagai perguruan tinggi dalam negeri maupun luar negeri. ${ }^{34}$

Sering sekali KH. Abdullah Syukri Zarkasyi dalam ceramahnya di hadapan para santri menukil dan meluruskan pendapat seorang alumni Gontor dan cendekiawan Muslim Prof. Dr. H. Nurcholis Madjid yang mengatakan bahwa Gontor itu hebat dengan bahasa Arab dan Inggrisnya saja. Padahal, menurut Pak Syukri, Gontor bukan hanya pengajaran bahasa Arab dan Inggrisnya saja, namun juga pendidikan mental yang luar biasa. Pendidikan mental inilah yang kemudian menghantarkan para santri siap menghadapi berbagai macam keadaan, termasuk dalam berkomunikasi dengan bahasa asing.

Kepercayaan diri dalam berbahasa merupakan buah dari pendidikan mental yang ditanamkan Gontor dengan berbagai macam pelajaran, cara, kegiatan dan aktifitas santri. Seperti dalam latihan kepemimpinan, penugasan-penugasan, muhadharah atau latihan berpidato, muhadatsah atau conversation, mengajar pelajaran sore, kepramukaan, drama contest dalam bahasa Arab dan Inggris, diskusi, ujian lisan, ilqa' mufradat atau penyampaian kosa kata dalam bahasa Arab dan Inggris setiap pagi, seminar-seminar yang menghadirkan native speaker, dan ujian praktik mengajar.

\section{Kesimpulan}

Pembelajaran bahasa Arab di PMDG dinilai sangat kompleks dan melibatkan seluruh aspek kehidupan para santri di dalam pondok.

${ }^{33}$ Karel A. Steenbrink, Almarhum yang Mukarram Pak Zarkasyi Seorang Pragmatikus dalam Pembinaan Pesantren, dalam Pondok Modern Darussalam Gontor, KH. Imam Zarkasyi di Mata Umat. (Ponorogo: Gontor Press, 1996). Hal. 904.

${ }^{34}$ Lance Castles, Gontor Sebuah Catatan Lama tentang Sekolah Islam, dalam dalam Pondok Modern Darussalam Gontor, KH. Imam Zarkasyi di Mata Umat. (Ponorogo: Gontor Press, 1996). Hal. 834. 
Pembelajaran bahasa Arab bagi PMDG tidak cukup hanya di kelas. Bahkan, hampir seluruh pelajaran di kelas menggunakan bahasa Arab, kecuali hanya beberapa pelajaran saja, seperti bahasa Inggris dan bahasa Indonesia.

Belum lagi penugasan dan disiplin berbahasa Arab yang diterapkan sangat ketat di PMDG. Sebab, tanpa pendisiplinan mustahil pembelajaran bahasa Arab dapat berjalan dengan baik dan optimal. Namun, disiplin pun tidak dapat ditegakkan jika tidak ada keteladanan. Dan, keteladanan berbahasa Arab di PMDG menjadi pemandangan umum. Keteladanan berbahasa Arab ini ditunjukkan oleh para pimpinan, guru-guru, dan para pengurus organisasi siswa serta asrama.

\section{Daftar Pustaka}

Al-A'zami, M.M. 2005. The History of the Qur'anic Text; from Revelation to Compilation, alih bahasa Sohirin Solihin, Anis Malik Thaha, Ugi Suharto dan Lili Yuliadi. Jakarta: GIP.

Al-Bukhari, Abu Abdillah Muhammad bin Isma'il. 2006. Matan Al Bukhari. Beirut: Dar al Fikr.

HS, Mastuki dan M. Ishom El-Saha (ed). 2003. Intelektualisme Pesantren, seri ketiga. Jakarta: Diva Pustaka.

https://ponorogo.go.id/letak-geografis/

Ihsan, Nur Hadi dan Muhammad Akrimul Hakim. 2004. Profil Pondok Modern Darussalam Gontor. Ponorogo: Pondok Modern Darussalam Gontor.

Pondok Modern Darussalam Gontor. 1996. KH. Imam Zarkasyi dari Gontor Merintis Pesantren Modern. Ponorogo: Gontor Press.

Thu'aimah, Ahmad Rusydi. 1989. Ta'lim al-'Arabiyyah lighair an-Nathiqin biha. Mesir: Jami'ah al Manshurah.

Tim Redaksi Nuansa Aulia. 2008. Himpunan Perundang-undangan Republik Indonesia tentang Sistem Pendidikan Nasional. Bandung: Nuansa Aulia.

Zarkasyi, KH. Abdullah Syukri. 2005. Manajemen Pesantren, Pengalaman Pondok Moder Gontor. Ponorogo: Trimurti Press.

Zarkasyi, KH Abdullah Syukri. 2005. Gontor dan Pembaharuan Pendidikan Pesantren. Jakarta: Rajawali Pers. 